\title{
Students' Data Literacy Ability in Physics Using the Physics E-Module Integrated with the Values of Pancasila During the Covid-19
}

\author{
Endah Kartika ${ }^{1, *}$ Ariswan ${ }^{2,}$ Maria Enjelina Suban ${ }^{1,}$ Zulaikha Ummul Arafah ${ }^{1}$ \\ ${ }^{1}$ Master of Physics Education, Faculty of Mathematics and Natural Science, Universitas Negeri Yogyakarta, \\ Indonesia \\ 2 Department of Physics Education, Faculty of Mathematics and Natural Science, Universitas Negeri \\ Yogyakarta, Indonesia \\ Corresponding author.E-mail: endahkartika.2019@student.uny.ac.id
}

\begin{abstract}
The purpose of this study was to determine the effect of structured learning media on students' data literacy skills. Media developed in the form of an integrated e-module with the practice of Pancasila values in impulse and momentum for class $\mathrm{X}$ using the Discovery Learning model. This type of research is a quasi-experimental with posttest only control group design. The sample in this study was 70 students of class X MIPA 1 and X MIPA 2 SMA Negeri 1 Prambanan which were divided into two as experimental and control class. The data collection technique was done by a test with an instrument in the form of a multiple choice that was facilitated by Google Form. Hypotheses were tested using independent t-test. There is a significant difference in data literacy skills among two classes based on the results of the $t$ test with a significance value $<0.05$. In addition, the average data literacy ability indicator shows that the average data literacy ability in the experimental class is better than the control class.
\end{abstract}

Keywords: E-modul, Pancasila, Discovery learning, Data literacy ability

\section{INTRODUCTION}

The world of education is currently facing challenges in preparing students who can compete in the Industrial Revolution of 4.0 [1]. The data literacy skill is needed to be equipping the students to face the industrial revolution [2]. That is related to the ease of accessing and obtaining data that flows through social media, television, cellphones, and various other communication tools[3].

Data literacy is something new, so the students need to know about it [2]. Data literacy is needed to understand and use data effectively in a series of decision-making processes [4]. This ability is also related to data-based decision making or data use processes [3]. The amount of data obtained starts to impact everyday life, so it needs to be dealt with wisely. The current digital era is like two inseparable blades because it has positive and negative impacts that cause changes in individuals' social, political, and even mental fields [5]. The digital era's negative impact, such as invalid data (hoaxes), can endanger someone who receives the data. No exception for students, with a large amount of data they obtain in every aspect of life, causes many who are not ready to evaluate these data critically [6]. Besides, the ability to interpret data is also important [7]. Hoax news can affect a person's mindset and behavior. Likewise, someone becomes panicked after seeing hoax news about the Covid-19 pandemic [8], being influenced by ideologies that conflict with Pancasila [5], and juvenile delinquency [9]. Therefore, it is crucial to train data literacy skills for students to avoid these negative impacts.

Efforts that can make them have good data literacy skills are training them in the learning process [10]. Data literacy skills can be taught and trained at every level of education, from primary education to postgraduate education [11]. Therefore, the training process of data literacy skills must be 
adjusted to students' characteristics and development. The process of training data literacy skills for high school students can be done using approaches [10], learning methods [11], media [12], and evaluation [2], which are appropriate for training data literacy skills.

An exciting relationship is found in a person's ability to understand ideology and literacy skills. Good literacy skills are influenced by a good understanding of the nation's ideology [13]. This is because ideology becomes a guideline for life in society and the state. When students understand their nation's ideology well, this will become a strong fortress for themselves to make decisions on the data obtained so that they are following the values contained in their ideology. Indonesia has a national and state ideology in the form of Pancasila. Pancasila consists of five fundamental values that function as the basis of the state, view of life, and the nation's ideology and state [14]. Efforts that can be made to train data literacy skills and deepen understanding of Pancasila for students include these values in the form of illustrations of daily activities. Illustrations of these activities can be explained physically and also reflect the practice of Pancasila values. These illustrations can be included in media or learning resources [15].

Based on the results of observing students' characteristics and the school environment, it is concluded that using smartphones as a means of operating learning media is considered useful in increasing students' interest in learning physics concepts. The use of electronic media can make learning physics more exciting and easier [16]. Therefore, the researcher decided to use the smartphone as a tool to operate the developed learning media. Learning using electronic media can provide benefits in terms of ease of storage, practicality, more economical, and easier distribution [17].

The implementation of learning amid the Covid19 pandemic throughout Indonesia was carried out online. This learning activity is under the Ministry of Education's recommendation through Circular Number 4 of 2020 concerning Implementation of Education Policy in an Emergency for the Spread of Coronavirus Disease (Covid-19). Also, it appeals from various governor, including the governor of the Special Region of Yogyakarta (DIY). This has led to the widespread use of Whatsapp Groups, Google Class, Google Form, Google Meet, Zoom, and many other applications to carry out learning activities from home (Study From Home). So, using learning media in e-modules is a practical choice to share with students in studying physics material independently from home but still monitored and facilitated to ask questions using Whatsapp Group.

Based on this description, the purpose of this article is to discuss the effect of structured learning media on students' data literacy skills. The media developed in the form of an integrated e-module with the practice of Pancasila values in impulse and momentum material for class X. During the Covid-19 the research was carried out online, assisted by Google Form and Whatsapp application.

\section{METHOD}

This type of research is quasi-experimental. The research design used is a Posttest Only Control Group Design. There are two research classes in this design, namely, the experimental class and the control class [18]Data literacy abilities were obtained after a test was carried out at the end of the meeting. The treatment given is a physics learning activity using an integrated e-module of Pancasila values in impulse and momentum material. The learning model used in this study is the Discovery Learning model. Table 1 presents the research design.

Table 1. The design of experiment

\begin{tabular}{|c|c|c|}
\hline Class & Treatment & Posttest Result \\
\hline Eksperiment & $\mathrm{X}$ & $\mathrm{O} 1$ \\
\hline Control & - & $\mathrm{O} 2$ \\
\hline
\end{tabular}

The points for the explanation of Pancasila values written in the e-module in this study are from TAP MPR No.1 / MPR / 2003. These points selected and adjusted to the indicators of data literacy skills used, including: 1) Developing association and cooperation between followers of different religions and beliefs so that harmony in life can build in the community; 2) Recognizing equality, equality of rights, and human obligations regardless of ethnicity, descent, religion, belief, gender, social position, skin color, and so on; 3) Able to place the unity, integrity and interests and safety of the nation and state as common interests above personal and group interests; 4) Not impose one's will on others; 5) Respect the rights of others.

The sample used in this study was 70 students in class X MIPA 1 as the control class and X MIPA 2 as the experimental class at SMA Negeri 1 Prambanan. The sampling technique used in this study was random sampling. The data collection instrument was in the form of a multiple-choice test sheet consisting 
of 12 questions arranged using Google Form. The hypothesis was tested by the independent t-test to see the difference in data literacy abilities between the experimental and control classes.

The analysis results obtained using SPSS, then also analyzed in each class for each indicator of data literacy ability using the equation used by the Next Generation Science Standards (NGSS) [19].

$\mathrm{NP}=\frac{\mathrm{R}}{\mathrm{SM}} \times 100 \%$

$\mathrm{NP}=$ percentage value, $\mathrm{R}=$ score on each indicator, and $\mathrm{SM}=$ maximum value. The results of the data literacy abilities that have been obtained are then categorized based on Table 2 .

Table 2. Data literacy categorization

\begin{tabular}{|c|c|}
\hline Percentage (\%) & Category \\
\hline $81<\mathrm{X} \leq 100$ & Very Good \\
\hline $61<\mathrm{X} \leq 80$ & Good \\
\hline $41<\mathrm{X} \leq 60$ & Average \\
\hline $21<\mathrm{X} \leq 40$ & Low \\
\hline $0<\mathrm{X} \leq 20$ & Very Low \\
\hline
\end{tabular}

\section{RESULT AND DISCUSSION}

This study aimed to determine the differences in student's data literacy skills taught by the e-module physics on the integrated impulse and momentum material of Pancasila values developed with the data literacy skills of students who are taught by learning media commonly used in class. Both are taught by the same learning model, namely Discovery. The data literacy ability indicator used was obtained based on the synthesis results according to several experts in Table 3.

Table 3. Synthesis of indicators and sub indicators of data literacy ability

\begin{tabular}{|l|l|}
\hline Indicators & Subindicators \\
\hline Collecting Data & Data Source Accuracy \\
\cline { 2 - 2 } & $\begin{array}{l}\text { Selecting Bound Variables based } \\
\text { on the data presented }\end{array}$ \\
\hline Analizing & $\begin{array}{l}\text { Analyze data based on the } \\
\text { concept of physics }\end{array}$ \\
\hline Interpretation & Interpret data in graphical form \\
\cline { 2 - 2 } Data & $\begin{array}{l}\text { Interpret data into mathematical } \\
\text { form }\end{array}$ \\
\hline Conclution & Formulate conclusions based on \\
\hline
\end{tabular}

\begin{tabular}{|l|l|}
\hline & the data format presented \\
\hline Experts have validated the media, devices, and
\end{tabular} Experts have validated the media, devices, and
struments used in the study. The e-module used has been validated in terms of material and media. The validation results show that the e-module is feasible with revisions to be used in research. Furthermore, the validated tools in this study included the Learning Implementation Plan (RPP) and Student Worksheets (LKPD). Both were validated and obtained results that were feasible with revisions for use in research. The instrument in the form of multiple-choice was also validated and obtained the result that the instrument was feasible with revision for research use.

The e-module is integrated with the practice of Pancasila values. The e-module is intended to make it easier for students to understand the concepts of impulse and momentum being taught. The concept is taught by examples of daily activities in the form of stories related to physics concepts. Besides, the module is also structured to adjust the indicators of data literacy abilities. This is intended to train the data literacy skills of students.

The post-test is carried out by the Google Form application in multiple choices, so that students' work can be directly analyzed. The use of Google Form is considered more effective and practical for conducting quizzes, surveys, or for collecting data from open-ended questions in a study [20]. Obtaining data from each indicator's research, data literacy ability can be analyzed by calculating the percentage of achievement of the test results measured in each indicator [21]. The post-test results in Table 4 showed that students' average data literacy ability in the experimental class was in a good category, while the control class included the average category.

Table 4, the lowest and highest scores for each class are same. However, based on the average class value, students' data literacy skills in the experimental class are better than the control class. This is because students in the control class can practice their data literacy skills using the e-module that has been prepared. The e-module which has been compiled in the stages of the material explanation follows the data literacy ability indicator; among others, there is a data collection section that tries to collect data in daily activities that reflect the values of Pancasila, and in these activities, there are the concepts of physics of impulses and momentum that can be analyzed. This section corresponds to indicators of collecting data. Examples are badminton and archery championships. After that, the concept is described in the analysis section. This part of the 
analysis corresponds to the data analysis indicators. This section trains students to analyze data, such as organizing and prioritizing data before finally being interpreted mathematically in the form of equations
[22]. The physics concept in the analysis section is also interpreted in the form of an equation. This is consistent with the data interpretation indicators.

Tabel 4. Comparison of data literacy abilities

\begin{tabular}{|c|c|c|c|c|c|}
\hline \multirow{2}{*}{ Class } & \multicolumn{2}{|l|}{$\begin{array}{l}\text { Number of } \\
\text { Students }\end{array}$} & \multicolumn{2}{|l|}{ Data Literacy Score } & \multirow{2}{*}{ Category } \\
\cline { 2 - 5 } & Minimum & Maximum & Average & \\
\hline Exsperiment & 35 & 25.00 & 91.67 & 62.38 & Good \\
\hline Control & 35 & 25.00 & 91.67 & 52.86 & Average \\
\hline
\end{tabular}

Table 5. The data distribution of data literacy ability

\begin{tabular}{|c|c|c|c|c|c|c|}
\hline \multirow{2}{*}{ Class } & \multicolumn{4}{|l|}{ Data Literacy Score } & \multicolumn{2}{l|}{ Category } \\
\cline { 2 - 7 } & Very Low & Low & Average & Good & Very Good & Average \\
\hline Exsperiment & - & 3 & 15 & 7 & 10 & Good \\
\hline Control & - & 6 & 19 & 8 & 2 & Average \\
\hline
\end{tabular}

Table 6. Data literacy ability t test results

\begin{tabular}{|c|c|c|c|c|}
\hline Tes & df & Mean Difference & Std. Error Difference & Sig. (2-Tailed) \\
\hline $\begin{array}{c}\text { Posttest } \\
\text { Eksperiment- } \\
\text { Control }\end{array}$ & 68.00 & 9.52 & 4.10 & 0.02 \\
\hline
\end{tabular}

Next, there is a conclusion section that concludes the concept analysis. This section corresponds to the indicators of infer data. The detailed comparison of students' data literacy abilities in the two classes is shown in Picture 1. Picture 1 illustrated that students' data literacy skills in the experimental class for each indicator have a better average value compared to the control class. The result shows that students in the experimental class have more data literacy skills than the control class. Table 5 presets The distribution of data literacy skills of students. The Independent t-test can significantly differ from the data obtained between the experimental class and the control class on their data literacy abilities. The independent t-test is included in the parametric statistical test, so as an initial prerequisite for whether an independent t-test can test data, it is necessary to know the data's homogeneity and distribution. Therefore, it is necessary to do a homogeneity test and normality test [23]. Both tests stated that the data were normally distributed and homogeneous (Sig.> 0.5). The results obtained indicate a significant difference in data literacy skills in the two-class groups.
The results of the $t$ test provide the fact that the data literacy skills of the two classes have a significant difference with a significance value below 0.05 (sig. <0.05). This indicates that the data literacy skills of students who are taught using the discovery learning model and the integrated module of Pancasila values are better. A significant difference can be seen in Table 5 and Figure 2 which shows that the data literacy skills of students in the experimental class are better than the control class.

The Independent t-test can significantly differ from the data obtained between the experimental class and the control class on their data literacy abilities. The independent t-test is included in the parametric statistical test, so as an initial prerequisite for whether an independent t-test can test data, it is necessary to know the data's homogeneity and distribution. Therefore, it is necessary to do a homogeneity test and normality test [23]. Both tests stated that the data were normally distributed and homogeneous (Sig.> 0.5). The results obtained indicate a significant difference in data literacy skills in the two-class groups. 
The results of the $t$ test provide the fact that the data literacy skills of the two classes have a significant difference with a significance value below 0.05 ( $\mathrm{sig}$. <0.05). The result can be seen detail in table 6. This indicates that the data literacy skills of students who are taught using the discovery learning model and the integrated module of Pancasila values are better. A significant difference can be seen in Table 5 and Picture 1 which shows that the data literacy skills of students in the experimental class are better than the control class.

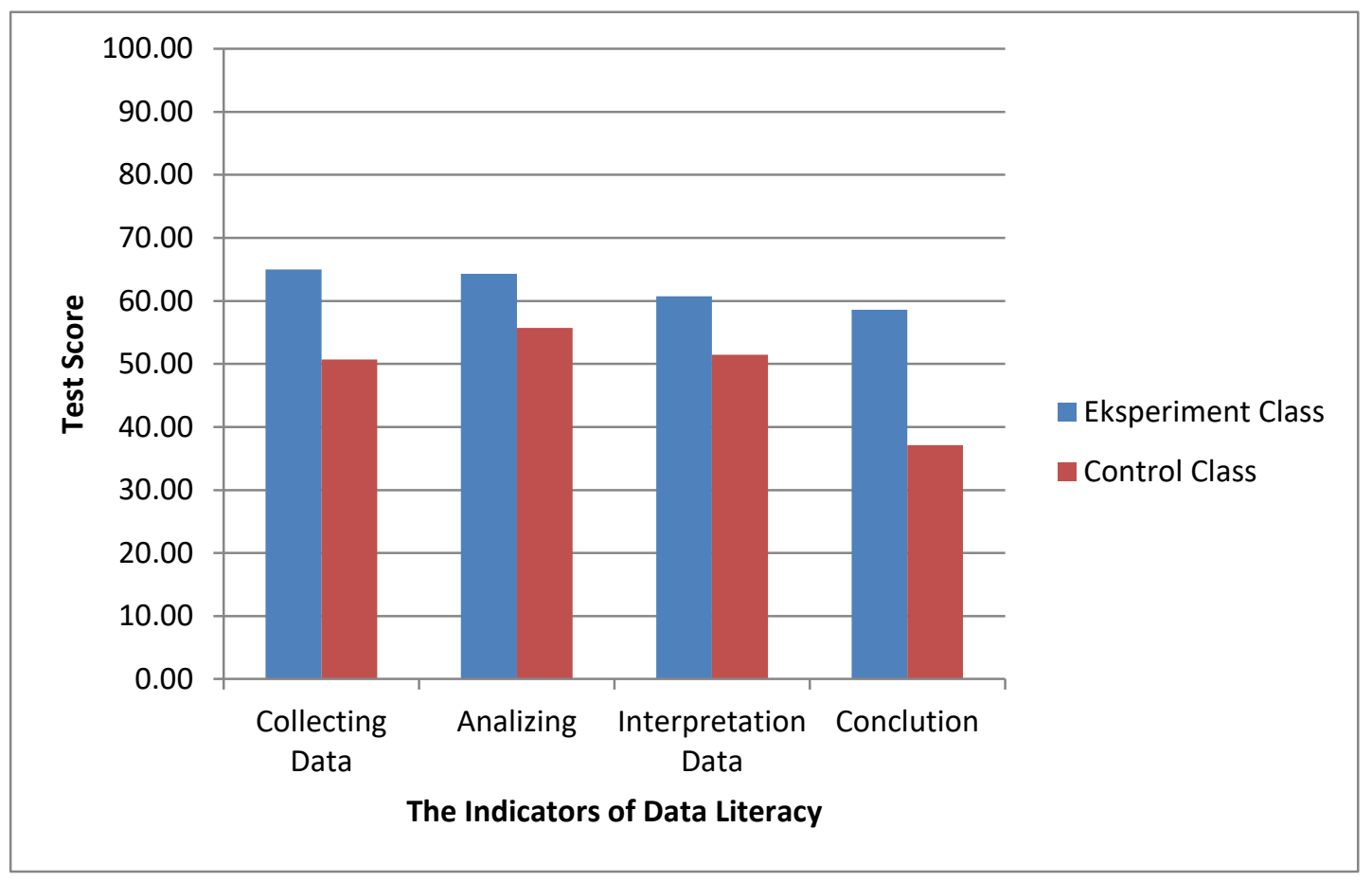

Figure 1 The comparison of data literacy abilities in each indicator

The Independent t-test can significantly differ from the data obtained between the experimental class and the control class on their data literacy abilities. The independent t-test is included in the parametric statistical test, so as an initial prerequisite for whether an independent t-test can test data, it is necessary to know the data's homogeneity and distribution. Therefore, it is necessary to do a homogeneity test and normality test [23]. Both tests stated that the data were normally distributed and homogeneous (Sig.> 0.5). The results obtained indicate a significant difference in data literacy skills in the two-class groups.

The results of the $t$ test provide the fact that the data literacy skills of the two classes have a significant difference with a significance value below 0.05 ( $\mathrm{sig}$. <0.05). This indicates that the data literacy skills of students who are taught using the discovery learning model and the integrated module of Pancasila values are better. A significant difference can be seen in Table 5 and Figure 2 which shows that the data literacy skills of students in the experimental class are better than the control class.
The results of the t-test provide the fact that the data literacy skills of the two classes have a significant difference with a significance value below 0.05 ( sig. <0.05). The results indicate that the data literacy skills of students taught by the discovery learning model with the integrated module of Pancasila values are better than the control class. A significant difference can be seen in Table 5 and Picture 1, which shows that students' data literacy skills in the experimental class are better than the control class.

This research is not perfect for students' data literacy skills because the existing treatment needs to be carried out continuously. This is intended so that students' data literacy skills can be maximized, and the impact of the e-module used is more visible. Besides, students' ability to understand concepts is also facilitated by the existence of easy-to-understand examples that also reflect Pancasila's values. 


\section{CONCLUSION}

The data analysis and discussion above results provide several conclusions on the research, namely, the data literacy skills of students in the experimental class are better than in the control class when using emodule material impulse and momentum integrated Pancasila values with the Discovery Learning model. The results of the average data literacy ability of the experimental class were better than the control class. There was a significant difference in the two classes' data literacy ability based on the results of the t-test.

\section{REFERENCES}

[1] Rahmita, D. Rosana, Profile analysis of data literacy capability based on NGSS junior high school students in Takalar, South Sulawesi, in: The 5th International Seminar on Science Education, Journal of Physics: Conference Series, vol. 1440, IOP Publisher, Bristol, 2020. DOI:

https://doi.org/10.1088/17426596/1440/1/01208 2

[2] M.A. Pratama, Supahar, D.P. Lestari, W.K. Sari, T.S.Y. Putri, V.A.K. Adiatmah, Data literacy assessment instrument for preparing 21 Cs literacy: preliminary study, in: The 5th International Seminar on Science Education, Journal of Physics: Conference Seies, vol. 1440, IOP Publisher, Bristol, 2020. DOI: https://doi.org/10.1088/17426596/1440/1/01208 5

[3] T.D. Reeves, S.L. Honig, A Classroom Data Literacy Intervention for Pre-Service Teachers, Teaching and Teacher Education (50) (2015) 90-101.

DOI: https://doi.org/10.1016/j.tate.2015.05.007

[4] E.B. Mandinach, E.S. Gummer, A Systemic View of Implementing Data Literacy in Educator Preparation, Journal of Educational Research and Policy Studies 13(2) (2013) 6-29. DOI:

https://doi.org/10.3102/0013189X12459803

[5] D. Rosana, D. Setyawarno, W. Setyaningsih, Development model of students' innert-depend strategies to face disruption era through best practice film of android based learning of pancasila character value, in: International Seminar on Science Education, Journal of Physics: Conference Seies, vol. 1233, no. 1, IOP Publisher, Bristol, 2019. DOI: https://doi.org/10.1088/17426596/1233/1/01209 $\underline{8}$

[6] T. Burress, E. Mann, T. Neville, Exploring Data Literacy Via A Librarian-Faculty Learning Community: A Case Study, The Journal of Academic Librarianship 46(1) (2020). DOI: https://doi.org/10.1016/j.acalib.2019.102076

[7] K. Kok, B. Priemer, W. Musold, A. Masnick, Students' Conclusions from Measurement Data: The More Decimal Places, The Better?, Physical Review Physics Educational Research 15(1) (2019) 1-7. DOI: https://doi.org/10.1103/PhysRevPhysEducRes.1 $\underline{5.010103}$

[8] R.N. Rahayu, Sensusiyati, Analisis Berita Hoax Covid - 19 di Media Sosial, Intelektiva: Jurnal Ekonomi, Sosial \& Humaniora 1(9) (2020) 6073.

[9] M. Nourollah, M. Fatemeh, J. Farhad, A Study of Factors Affecting Juvenile Delinquency, Biomedical and Pharmacology Journal 8 (2015) 25-30. DOI: https://doi.org/10.13005/bpj/551

[10] R. Bhargava, The International Encyclopedia of Media Literacy, Wiley Online Library, 2019.

[11] C. Ridsdale, J. Rothwell, M. Smit, H. AliHassan, M. Bliemel, D. Irvine, D. Kelley, S. Matwin, B. Wuetherick, Strategies and Best Practices for Data Literacy Education Knowledge Synthesis Report, Dalhousie University, 2015.

[12] Susilawati, C. Huda, Masturi, S.P. Saputro, N. Khoiri, Pre-service teacher ideas about designing demonstration set in physics education program, in: UNNES Physics International Symposium, Journal of Physics: Conference Seies, vol. 1170, IOP Publisher, Bristol, 2019.2 DOI: https://doi.org/10.1088/17426596/1170/1/01204 $\underline{6}$

[13] Z.D. Rusnalasari, H. Algristian, T.P. Alfath, A.D. Arumsari, I. Inayati, Students Vulnerability and Literacy Analysis Terrorism Ideology Prevention, in: 2nd International Conferenceon Statistics, Mathematics, and Research, Journal of Physics: Conference Seies, vol. 1028, IOP Publisher, Bristol, 2018. DOI: https://doi.org/10.1088/17426596/1028/1/01208 9 
[14] F. Munabari, Reconciling Sharia with 'Negara Kesatuan Republik Indonesia: The Ideology and Framing Strategies of The Indonesian Forum of Islamic Society (FUI), International Area Studies Review 20(3) (2017) 242-263. DOI: https://doi.org/10.1177/2233865917699066

[15] A.M. Sari, I. Wilujeng, A. Satriana, The development of optical devices learning book integrated with Pancasila practice values, in: The 5th International Seminar on Science Education, Journal of Physics: Conference Seies, vol. 1440, IOP Publisher, Bristol, 2020. DOI:

https://doi.org/10.1088/17426596/1440/1/01203 $\underline{6}$

[16] T.A. Sukma, M. Mundilarto, N.D. Putri, Local wisdom-Based Electronic Book on Newton's Law, Jurnal Ilmiah Pendidikan Fisika Al-Biruni 8(2) (2019) 197-206. DOI: https://doi.org/10.24042/jipfalbiruni.v0i0.4368

[17] M. Mohammed, A. Ebied, S. Ahmed, A. Rahman, The Effect of Interactive E-Book on Students' Achievement at Najran University in Computer in Education Course, Journal of Educaion and Practice 6(19) (2015) 71-83.

[18] F.N. Solekha, S.H. Noer, P. Gunowibowo, Pengaruh Model Pembelajaran Kooperati Tipe Grup Investigation terhadap Kemampuan Komunikasi Matematis Siswa, Jurnal Penelitian Pendidikan Matematika 1(1) (2013). DOI: https://doi.org/10.1088/17426596/1440/1/01208 $\underline{2}$
[19] Rahmita, D. Rosana, Profile analysis of data literacy capability based on NGSS junior high school students in Takalar, South Sulawesi, in: The 5th International Seminar on Science Education, Journal of Physics: Conference Seies, vol. 1440, IOP Publisher, Bristol, 2020. DOI:

https://doi.org/10.1088/17426596/1440/1/01208 2

[20] A.Z. Mansor, Managing student's grades and attendance records using google forms and google spreadsheets, in: Procedia - Social and Behavioral Sciences, vol. 59, Elsevier, Amsterdam, 2012, pp. 420-428. DOI: https://doi.org/10.1016/j.sbspro.2012.09.296

[21] N. Wulandari, N. Wulandari, Analisis Kemampuan Literasi Sains pada Aspek Pengetahuan dan Kompetensi Sains Siswa SMP pada Materi Kalor, Edusains 8(1) (2016) 6673. DOI: https://doi.org/10.15408/es.v8i1.1762

[22] W.B. Kippers, C.L. Poortman, K. Schildkamp, A.J. Visscher, Data literacy: What Do Educators Learn and Struggle with during A Data Use Intervention?, Studies in Educational Evaluation 56 (2018) 21-31. DOI: https://doi.org/10.1016/j.stueduc.2017.11.001

[23] E. Lestari, Ardisyahputra, R. Komala, The Science Literasi Ability of Students in Junior High School Reviewed by The Literacy Ability of Teachers and School Geographical Location, Edusains 11(1) (2019) 79-85. DOI: https://doi.org/10.15408/es.v11i1.8602 